Please cite this article as:

Frattini F., Bianchi M., Franzò S. (2019).

Identifying Factors Influencing the Price of Technology Licenses: a Framework Grounded in Negotiation Research.

International Journal of Innovation Management, vol. 23 (1) pp. 1-34.

(DOI: https://doi.org/10.1142/S1363919619500397) 


\title{
Identifying Factors Influencing the Price of Technology Licenses: a Framework Grounded in Negotiation Research
}

\begin{abstract}
This paper focuses on the issue of pricing in technology licensing transactions, by developing a framework grounded in negotiation research which identifies the factors affecting the price of a technology license. The different components of the framework are illustrated by using several examples of technology licensing deals from the biopharmaceutical industry. The paper contributes to licensing research by shedding light on the mechanisms underlying the formation of price in the market for technologies. It has also interesting practical implications because it helps licensing managers and chief technology officers gain an overarching view on the pricing of technology license, which will hopefully help them in this delicate stage of the licensing process.
\end{abstract}

\section{Introduction}

The weight of intellectual intangible assets on firms' value has significantly grown in the last decades (Razgaitis, 2006), and it now often exceeds $70 \%$. Not only have these assets become key sources of competitive advantage for companies in their own markets, but they are increasingly commercialized and transferred to external organizations (Bianchi et al., 2014; Danneels and Frattini, 2018), used as bargaining chips (Hall and Ziedonis, 2001), and as fundamental underlying resources exchanged in licensing agreements and collaborative alliances among firms (Gans and Stern, 2003). This is especially true in the case of technological assets, i.e. patents, know-how and ideas.

As technology transactions, especially those conducted through a licensing contract, are now a large and important economic activity of firms, market for technologies - defined by Arora and Gambardella (2008) as the trade of technology disembodied from physical goods - have emerged and expanded in the last years. In 2008 the worldwide size of markets for technologies was estimated to be well over 200 billion dollars of revenues per year (Arora and Gambardella, 2008). In the last decade, research on Open Innovation has highlighted several changes in firms' approach to the strategic management of technology (Bianchi et al., 2011c), documenting both their increased reliance on external sources of technology to feed the innovation process (Chatterji, 1996; Roberts, 2001; West and Bogers, 2014), as well as their enhanced attitude toward using multiple channels for technology exploitation (Lichtenthaler, 2004; Bianchi et al., 2014). Firms are now described as active both on the demand and supply side of the market for technology. In sum, this research shows that the growing adoption of the Open Innovation paradigm, in both its Inbound and Outbound 
dimensions (Chesbrough and Crowther, 2006), has further spurred the growth of technology transactions.

The inherent complexity of deal-making in these transactions represents a strong barrier to the further development of the market for technologies. Razgaitis (2004) finds that, out of 100 licensable technologies, only 3-4 licensing deals are ultimately signed. The main sources of complexity, which are responsible for the high level of transaction costs in the markets for technologies (Gambardella et al., 2007), and thus hinder the successful realization of agreements, include:

- the identification of potential licensees (Razgaitis, 2004; Escher, 2005; Zuniga and Guellec, 2009). In the technology market, there is only a limited number of organizations that might be interested in a technology and very little or no advertising activities for technologies on sale. This also stems from the Arrow's information paradox (Arrow, 1996)

- the pricing of technological assets, due to their intangible and idiosyncratic nature (Chiesa et al., 2003). Accordingly, the valuation of these assets relies heavily on people's subjective judgments about future profitability and prospective market opportunities. The earlier stage the technology is, the more complex its pricing is;

- the negotiation effort: an initial price proposal is seldom accepted without discussion in a licensing negotiation (Berkman, 2002). Differences in expectations on the future performance of a technology and in the bargaining power of the counterparts cause many negotiations to fail, in particular about $47 \%$ of those that are initiated (Razgaitis, 2004);

- the long-term scope of licensing deals, which requires risk sharing and collaborative behavior among the partners.

The goal of this paper is to shed light on the process through which the price of technology licenses is formed, and in particular on the factors that influence this price. The decision to focus on the price of licenses is due to the fact that licensing is at the basis of different types of agreements through which a technology can be exchanged between two parties (such as research collaborations, co-development, co-marketing, besides of course pure licensing). As a result, licensing is responsible for the largest part of the value of the market for technology globally (Aggarwal and Hsu, 2009).

The importance of the topic which is the focus of this paper is confirmed by several surveys of the Licensing Executive Society (LES), according to which the major cause for licensing

\footnotetext{
${ }^{1}$ The act of marketing technological knowledge comprises the risk of disclosing its relevant aspects to potential buyers who may apply the knowledge at close to zero marginal costs.
} 
deal breakdown is the inability of the counterparts to reach mutually acceptable financial terms during negotiations. However, prior research on the market for technologies and licensing has surprisingly neglected this topic. A better understanding of the pricing process and its drivers may help reduce the transaction costs that hinder firms' reliance on technology commercialization strategies (Bianchi et al., 2011a; 2011b), while enhancing the ability of licensing specialists (such as licensing managers) to close value-creating deals. In doing so, this research may contribute to a further growth and development of markets for technologies, as advocated by Arora and Gambardella (2008).

To reach its objective, this paper develops a framework based on negotiation research, which identifies the factors affecting the price of a technology license and the mechanisms through which they exert their influence. The framework is designed with the aim to help understand how the price of technology licenses is formed. The components of the framework are illustrated by using several examples of technology licensing deals from the bio-pharmaceutical industry.

The remainder of the paper is structured as follows. Section 2 provides a brief review of the literature. Section 3 builds and explains the overall structure of our framework, whereas Section 4 explains the choice to focus on the biopharmaceutical industry and how information has been collected and analysed for our illustrative cases from the biopharmaceutical industry. Section 5 presents the details of the framework and illustrates them through the use of the illustrative examples. Finally, Section 6 discusses implications and highlights avenues for future research.

\section{Literature review}

Licensing research and studies on the market for technologies have mostly adopted a strategic viewpoint and have disregarded the issue of how the price of technology licenses is formed. Several papers have focused on the licensing dilemma (Fosfuri, 2006), the decision of whether to internally or externally exploit a technology, and on the determinants that increase the propensity to out-license technology by firms, among which the strength of Intellectual Property (IP) protection and the lack of complementary assets (Arora and Ceccagnoli, 2006; Gans and Stern, 2003; Kani and Motohashi, 2012), the generality of technology, the degree of product market fragmentation (Gambardella and Giarratana, 2007; Gambardella and Giarratana, 2013), and the appropriability regime (Teece, 1986). Other studies have searched for the antecedents of superior performance in out-licensing, such as the development of a reputation as a valuable technology provider (Lichtenthaler and Ernst, 2007) and the level of trust (Jensen et al., 2015). 
Very few works have looked into the contract-related issues underlying technology licenses (e.g., Anand and Khanna, 2000, Sakakibara, 2010). Some scholars have attempted to determine a reasonable royalty rate and suitable upfront fees, by focusing on a particular industry (Finnegan and Mintz, 1978; Muir, 1986). Beggs (1992) argues indeed that the levels of royalty rate vary across industries, and Kemmerer and $\mathrm{Lu}$ (2008) finds that there is a linear relationship between royalty rates and various profitability measures of different industries, suggesting that the licensing market is efficient and that cost structure and profitability across sectors have been factored into royalty rate negotiation. Another contribution from Leone and Oriani (2008) studies the remuneration structure of patent licenses and finds that royalty rate, the clause of exclusivity, and the individual nature of the licensor are factors that negatively affect the initial licensing fee, while the scope of the license (number of patents exchanged), its duration, and the level of market and technical uncertainty increase the upfront fee. However, this literature often focuses on single, specific contractual issues of licensing agreements, failing to provide a comprehensive analysis of the factors and mechanisms that drive the price of technology licenses.

Some studies have adopted a process perspective to outline the steps firms go through in the technology commercialization process, which often entails the realization of a technology licensing deal (Bianchi et al., 2011a; Arora et al., 2013; Danneels and Frattini, 2018). These papers identify pricing as a critical step in the process, but do not study in detail the mechanisms through price is formed in technology licensing deals.

Another relevant stream of research focuses on the methods and techniques used in practice to determine the value of technological assets (Chiesa and Frattini, 2009). The most popular monetary evaluation approaches are the Cost, Market and Income methods, which are based on different assumptions and require the estimation of different quantitative parameters for their proper application (Park and Park, 2004). The problem with these methods is that they only give a preliminary indication of the value of a technological asset, based on the quantitative variables that can be captured in a monetary approach. In practice, the final value of a technology license is often substantially different from the price suggested by these methods. This happens because many qualitative factors play a role in the evaluation process and, especially, in the negotiation phase. These factors cannot be captured through a monetary approach and have subtle and difficult to predict impacts on the price of a technology license. Some attempts have been made to identify these factors (see, e.g., Chiesa et al., 2007), but they are not exhaustive in explaining the process through which these factors impact the price of the technology license. 
This paper contributes to our understanding of the qualitative factors influencing the price of technology licenses by developing an interpretative framework grounded in negotiation research, and by illustrating its components by using several cases of technology licenses in the bio-pharmaceutical industry.

\section{Factors Influencing the Price of a Technology License: an Interpretative Framework}

In the context of licensing, pricing can be modeled as an interactive process that sees the participation of two parties, the prospective licensor and the licensee. Such process consists of two subsequent phases, i.e. (i) preparation and (ii) negotiation (See Figure 1).

\section{Figure 1 - A Model of the Pricing Process in the Context of Licensing}

\begin{tabular}{|c|c|c|c|c|c|}
\hline \multirow{2}{*}{\begin{tabular}{|c|} 
Parties \\
LICENSOR \\
\end{tabular}} & Phase 1 & \multicolumn{2}{|c|}{ Output } & \multirow{3}{*}{ NEGOTIATION } & Output \\
\hline & PREPARATION & \begin{tabular}{|ll|}
\multicolumn{1}{|c|}{$\begin{array}{c}\text { Self- } \\
\text { assessment }\end{array}$} \\
- Target \\
point \\
- Walk- \\
away point \\
- & Preferred \\
& royalty \\
& structure \\
and other & contractual \\
issues
\end{tabular} & 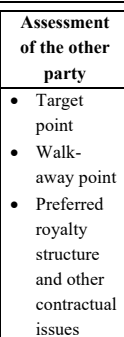 & & $\begin{array}{l}\text { - Final price and } \\
\text { royalty } \\
\text { structure } \\
\text { - Agreed } \\
\text { contractual } \\
\text { issues }\end{array}$ \\
\hline LICENSEE & PREPARATION & \begin{tabular}{|ll|}
\multicolumn{1}{|c|}{$\begin{array}{c}\text { Self- } \\
\text { assessment }\end{array}$} \\
- Target \\
point \\
- Walk- \\
away point \\
- Preferred \\
royalty \\
structure \\
and other \\
contractual \\
issues
\end{tabular} & \begin{tabular}{|l|}
$\begin{array}{c}\text { Assessment } \\
\text { of the other } \\
\text { party }\end{array}$ \\
- Target \\
point \\
- Walk- \\
away point \\
- Preferred \\
royalty \\
structure \\
and other \\
contractual \\
issues
\end{tabular} & & $\begin{array}{l}\text { structure } \\
\text { - Agreed } \\
\text { contractual } \\
\text { issues }\end{array}$ \\
\hline
\end{tabular}

The preparation phase is independently carried out by each party involved in the transaction and includes, among other tasks: (i) the collection and processing of information related to the focal technology, to the counterpart, to the market and to the technological environment; (ii) the execution of intelligence activities; (iii) the application of valuation methods. 
According to Thompson (2012), a proper preparation phase should aim at determining the following quantities (with reference to the case of the prospective licensor ${ }^{2}$ ):

- target point (or aspiration point), which represents the upper price limit that a licensor can get from the licensee in an ideal negotiation;

- walk-away point, which refers to the lowest price that the licensor is willing to accept from a licensee. The minimum willingness to accept is bounded by the existence of a viable alternative. The walk-away point is the monetary quantification of the licensor's best alternative to a negotiated agreement (BATNA), i.e. its next best option in the case that the agreement is not reached: in practice it means that "negotiators should be willing to accept any set of terms superior to their BATNA and reject outcomes that are worse than their BATNA" (Thompson, 2012, p. 15);

- the desired royalty structure and other contractual issues. The price of a license is seldom reflected in a single value but rather consists of different forms of payments: a lump-sum fee (or up-front payment) paid upon signing the contract, milestone payments conditional on the achievement of specific targets, and running royalties generally computed on a percentage of the amount of net sales. Also, when negotiating a licensing contract, a set of clauses are usually at stake: exclusivity of rights; territorial extent of rights; fields of use restrictions; duration of the agreement, etcetera. During the preparation phase, the licensor has to single out these issues, to identify alternative courses of action for each issue (e.g., exclusive as opposed to non-exclusive rights) and to determine a variety of different combinations of the issues that are of equivalent value to him.

In addition to the self-assessment, it is critical that the negotiator attempts to understand the other party's interest in the deal. Above all, "[p]robably the most important piece of information a negotiator can have in a negotiation is the BATNA of the other party" (Thompson, 2012, p. 27). By knowing the BATNA of the counterpart, the licensor can estimate its walk-away point, i.e. the maximum price that the licensee is willing to pay.

Following the preparation phase, the negotiation phase consists of several rounds of proposals and counterproposals, in which the parties interact in the attempt to converge over an agreed deal. If this is not the case, the deal breaks down. Drawing from standard negotiation literature, we model the negotiation setting with the ZOPA (zone of possible agreements) model (see Figure $2^{3}$ ). Assuming at first a single price structure for the licensing agreement, the ZOPA model reports the quantities derived by each counterpart in the preparation phase (i.e. the target and walk-away points) along a one-dimensional

\footnotetext{
${ }^{2}$ The same quantities, in the opposite fashion, are assessed by the prospective licensee too.

${ }^{3}$ The model represents the view of an external observer to whom all values from licensor and licensee are transparent.
} 
axis of increasing monetary value. The area between each party's walk-away points is named bargaining zone, or surplus (Lax and Sebenius, 1986; Thompson, 2012). The bargaining zone is a measure of the value that a negotiated agreement offers to both parties over the alternative of not reaching a settlement.

Figure 2 - A Representation of the ZOPA Model

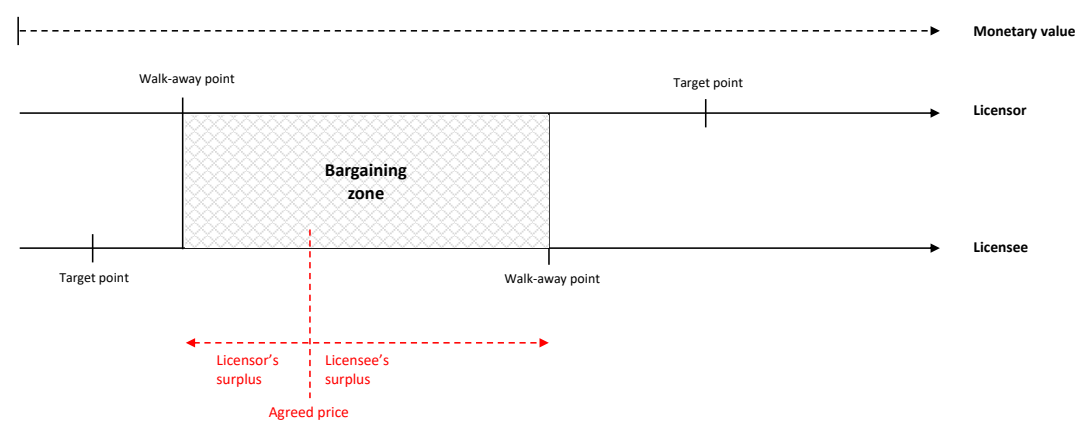

In the application of the ZOPA model, two cases may occur:

1) the bargaining zone is negative. In this case, the walk-away point of the licensee is lower than that of the licensor and therefore an agreement cannot be reached. In this situation, negotiators should exercise their best alternative agreement;

2) the bargaining zone is positive, as in Figure 2. Under such circumstance, a mutual settlement is profitable for both parties since it is most favorable than resorting to BATNAs. The final price of the license will fall in the bargaining zone, above the licensor's walk-away point and below the licensee's walk-away point (Raiffa, 1982). The positive difference between the agreed price and a party's walk-away point is defined as the negotiator surplus. This can be intended as the slice of the total pie (the bargaining surplus) accruing to each negotiator. The objective of each party is to maximize its surplus, ideally closing the deal at a price corresponding to the counterpart's walk-away point, thus claiming the entire pie for himself.

Finally, the output of the negotiation phase, and of the entire pricing process, is the agreed licensing contract, consisting of a price and related contractual issues. This type of negotiation is defined by Thompson (2012, p. 42) as a mixed-motive negotiation: "in fact, negotiators are motivated to cooperate with the other party to ensure that settlement is reached in the case of a positive bargaining zone, but they are motivated to compete with one another to claim as much of the bargaining surplus as they can”. 
After using negotiation literature to model the pricing process of a technology license, we now move to discuss the factors that influence the price of the license, which represents the main dependent variable of our interpretative model (see Figure 3 for a graphical representation).

\section{Figure 3 - An Interpretative Framework of the Factors Influencing the Price of a}

\section{Technology License}

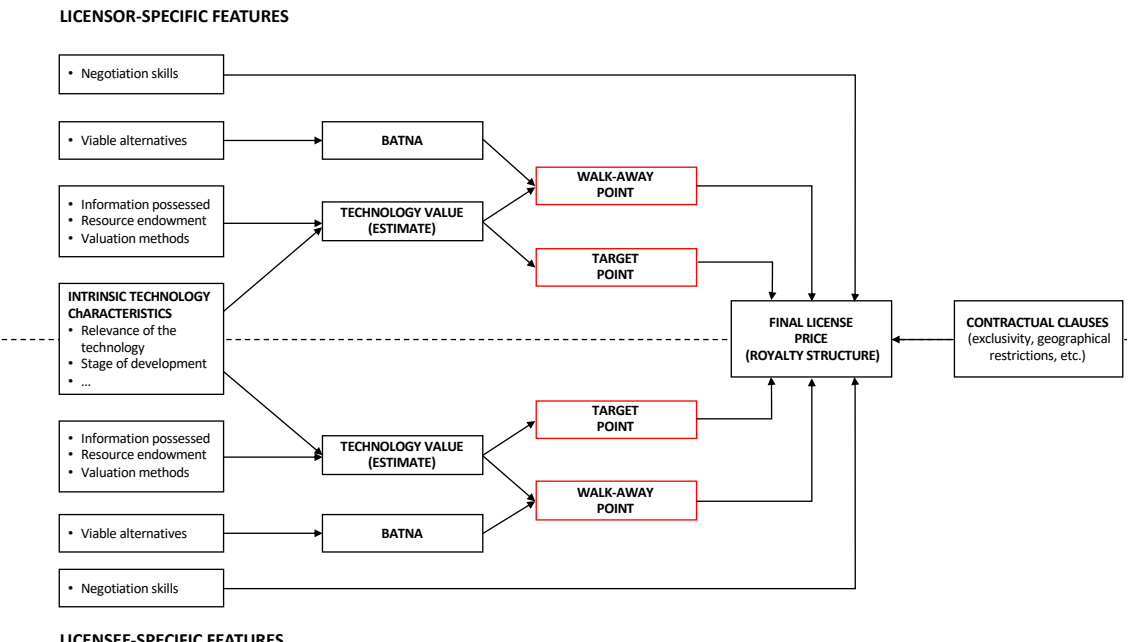

According to this framework, the price of a license depends on the values of the walk-away points and of the target points of the counterparts (Thompson, 2012). Therefore, we now ask ourselves: what factors influence these two quantities? Obviously, a key driver is the value of the technology to be exchanged through licensing. The maximum price that a licensor can aspire to earn and the minimum that it is willing to accept - so as the minimum price that a licensee can aspire to pay and the maximum that he is willing to pay - all stem from an assessment of the value of the underlying technology and its ability to generate cash.

However, as mentioned above, a technological asset cannot have a definite, precise, and universally valid value. King (2002, p. 2) argues that the value of a technology "cannot be stated in the abstract; all that can be stated is the value of a thing in a particular place, at a particular time, in particular circumstances". Indeed, the determinants of the value of a technology include not only the intrinsic characteristics of the asset (e.g., its stage of 
development), which could be objectively assessed, but also specific features of the counterparts involved in the licensing transaction (e.g., the quality of the licensee's downstream complementary assets). Therefore, the factors included in our framework as those influencing the value of the technology (and, as a consequence, the final license price) can be distinguished into: (1) intrinsic characteristics of the technology; (2) specific features of the licensor; (3) specific features of the licensee; (4) specific features of the dyad licensor-licensee; (5) specific features of the contract (i.e., contractual clauses).

If we adopt an Income approach for the valuation of the technology (see, e.g., Chiesa and Frattini, 2009), the value of the latter derives from its profitability (the prediction of future revenues net of the relevant costs from using the technology) and its associated risk (the probability of success or failure of that prediction). A high level of profitability increases the value of the technology, whereas a high risk reduces it. The expected profitability of a technology is a function of its relevance and uniqueness compared to alternative technologies, the market size of the application domain, the expected market penetration and its cost structure, among the others (for a comprehensive list of these factors, see Chiesa et al., 2007). The risk is instead a function of its stage of development, of the IP strength and validity, of the technical uncertainty on further development and of the market uncertainty on the commercial performance of the product incorporating the technology.

In particular, the assessment of the technology value is influenced by these specific features of the counterparts:

- information possessed by each party. To appraise a technology, each negotiator has to make subjective predictions about future market prospects and technical details. The information in the hand of each party drives different expectations and judgments about uncertain events yet to come;

- resources endowment of each party. The assets and capabilities owned by each party affect the value of a technology. For instance, the quality of downstream complementary assets (e.g., market access, distribution channel, customer list) of the licensee may increase the expected sales of the products incorporating the technology, while its $R \& D$ expertise helps reduce the risk of technical failure;

- methods applied to estimate the technology's value. In addition to the Income approach, a negotiator may use for valuation purposes the Cost approach, which considers the costs involved in the development of the technology, and the Market approach, which considers the price at which comparable assets have been exchanged in arm's length transactions (for a detailed description of IP valuation methods see also Smith and Parr, 2000). The application of different methods by each party may return very dissimilar results in terms of technology's value. 
A key factor influencing the walk-away points of the counterparts are the alternatives to the negotiated agreement that each party has. The walk-away point is indeed the monetary quantification of the best of these alternatives (BATNA). In the licensing context, the options available to the licensor could be: maintaining the unique right to exploit the technology; licensing to another bidder; licensing to more parties as well as exploiting the technology itself. If licensing is pursued to enter foreign countries, other options could be: foreign direct investments to establish commercial subsidiaries in the target country; establish a joint venture with a local player. It should be also noted that the value of the technology affects the existence of alternatives: indeed, the more valuable a technology is, the more likely it attracts the interest of other companies.

On the contrary, options available to the licensee may be: internally developing another technology with similar functions (without infringing IP rights); licensing alternative technologies from other inventors; doing without it. In general, the absence of a viable alternative enhances the strategic need of the licensee for the technology at issue and in turn weakens its bargaining position and increases its willingness to pay.

Besides the target and walk-away points, the final price also depends on the negotiation skills of the parties. The ability to interpret the other party's strategic interests, preferences and alternatives are crucial for appropriating a bigger slice of the pie (the bargaining surplus). Also, a negotiation style that builds trust and sharing of information ensures that settlement is reached in the case of a positive bargaining zone and simultaneously to claim as much of the bargaining surplus as possible (Thompson, 2012).

Finally, the set of clauses in the licensing contract, which detail the critical aspects of the up-coming collaboration, influence the agreed price of the license. For instance, an exclusive license will be more expensive than a non-exclusive one, as it provides a limited monopoly to the licensee on the application of this technology and prevents the owner from licensing the technology to other interested parties. Similarly, the stricter the agreement's geographical extension, the lower the expected price of the license is. Contractual clauses are often matters under tough dispute as the counterparts may have different interests and preferences across these issues. 


\section{Illustrative Examples from the Bio-pharmaceutical Industry}

We complemented the development of our theoretical framework with examples of eight companies active in the bio-pharmaceutical industry and ten technology licensing deals in which they have been involved and for which they were available to share detailed information, in addition with other general experiences from deal making.

We chose to focus on this industry because bio-pharmaceutical firms are among the most active in technology licensing agreements (Hagedoorn, 1993; Rogers et al., 2004; Lane and Probert, 2007; Baldi and Trigeorgis, 2015). Such agreements are technology-based transactions allowing for the exchange of patented (or patentable) R\&D results characterized by the absence of previous business history (Razgaitis, 2003). A combination of strong IP protection, high costs of assembling downstream complementary assets, long and highly risky new drug development processes make licensing a diffused strategy in this sector (Gans and Stern, 2003; Lane and Probert, 2007).

Indeed, research has acknowledged that the bio-pharmaceutical industry is a fertile ground for the adoption of Open Innovation (Allarakhia and Walsh, 2011; Bianchi et al., 2011c; $\mathrm{Hu}$ et al., 2015; Wang et al., 2015; Wu et al., 2016), in which licensing plays a particular important role in both inbound and outbound Open Innovation processes (Hu et al., 2015). Among the organizational modes used to implement Inbound Open Innovation, inlicensing - which usually occurs during pre-clinical tests - involves bio-pharmaceutical firms acquiring the rights to use a specific drug from an external player (e.g., another biotech firm, a pharmaceutical company or a university) (Bianchi et al., 2011c). On the other hand, among the organizational modes used to implement Outbound Open Innovation, out-licensing - which usually takes place during clinical tests - involves biopharmaceutical firms licensing out a drug, mainly to big pharmaceutical companies (Bianchi et al., 2011c).

Licensing helps bridge the widening gap between the amount of internally generated drugs for clinical trials by large-scale pharmaceutical firms (Paul et al., 2010), which have commercialization needs and world-class capabilities, and the generation of novel compounds by entrepreneurial bio-pharmaceutical firms, which focus on R\&D-related activities along the value chain in the bio-pharmaceutical industry (Stuart et al., 2007). In this regard, it should be noted that $38 \%$ of the 691 new chemical compounds approved by the US Food and Drug Administration (FDA) between 1963 and 1999 were licensed-in (DiMasi, 2001), while in 2001, 9 of the top 10 pharmaceutical companies licensed-in more than $40 \%$ of their newly marketed molecular entities (Cap Gemini Ernst \& Young, 2001).

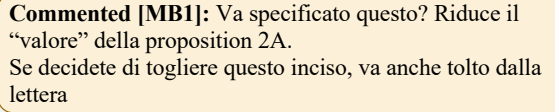

Commented [MB2]: Vedi commento sopra 
For these reasons, we considered the bio-pharmaceutical industry to be an "extreme" setting (Siggelkow, 2007) where to discuss and analyze the mechanisms underlying price formation in technology licensing deals. Our purpose here is not to report on an inductive study, but to use these examples as illustration. Therefore, we present the illustrative example after the explanation of the overall logic underlying our framework to provide a clearer and more empirically-grounded description of its components (Siggelkow, 2007). Using these illustrations, we clarify theoretical concepts and relationships, and show how the different variables included in our interpretative framework are actually applied (Siggelkow, 2007: 22). Accordingly, this approach allows for a closer alignment between theory and data (Glaser and Strauss, 1967).

The choice of the bio-pharmaceutical companies and deals on which to focus was guided by convenience sampling criteria (Etikan et al. 2016). In particular, two of the authors have had long-lasting research collaborations with the selected firms, as part of a broader research project aimed at mapping patterns of innovation along the bio-pharmaceutical value chain. This has allowed us to focus on companies with significant experience with licensing deals and to have access to data and information that otherwise would have been impossible to gather.

We have drawn on multiple and varied sources of information to develop the illustrative cases. Specifically, the collection of data lasted from 2010 to 2016, including company websites and other secondary sources of data, such as financial and business reports, presentations, press releases, magazine articles, and books. Moreover, the data collected from secondary sources were corroborated with face-to-face interviews conducted with CEOs, Heads of Business Development, and Licensing Managers. Data have been analyzed through an iterative process, stepping from data to theory, and vice-versa (Strauss and Corbin, 1998). This has allowed us to refine our interpretative framework, clarify its conceptual components, and illuminate how theoretical concepts work in practice. Finally, in order to ensure the consistency of our data, we triangulated the different sources independently, analyzed the collected data, and discussed our interpretations during meetings aimed at addressing potential misinterpretations and dissimilar views (De Massis

et al., 2016). Table 1 provides some background information about the eight companies that we studied and about the interviewees.

Table 1. Background information about the selected companies (the real names of the companies have been blinded for confidentiality reasons) 


\begin{tabular}{|c|c|c|c|}
\hline Companies & $\begin{array}{c}\text { Year of } \\
\text { foundation }\end{array}$ & Therapeutic Areas & Role of Interviewees \\
\hline Company A & 1996 & $\begin{array}{l}\text { Inflammation } \\
\text { Cardiovascular }\end{array}$ & $\begin{array}{c}\text { Managing Director } \\
\text { Executive Vice President of Business } \\
\text { Development }\end{array}$ \\
\hline Company B & 1997 & $\begin{array}{c}\text { Rheumatology } \\
\text { Respiratory } \\
\text { Diabetes } \\
\text { Dermatology } \\
\text { Oncology } \\
\text { Central Nervous System }\end{array}$ & $\begin{array}{c}\text { Head of Licensing \& Business } \\
\text { Development } \\
\text { CEO }\end{array}$ \\
\hline Company $\mathrm{C}$ & 1999 & Central Nervous System & Senior Licensing Manager \\
\hline Company D & 2006 & Oncology & CEO and co-founder \\
\hline Company E & 2004 & Oncology & Head of Business Development \\
\hline Company $\mathrm{F}$ & 1996 & Oncology & $\begin{array}{c}\text { Head of Business Development } \\
\text { Licensing manager } \\
\text { CEO } \\
\end{array}$ \\
\hline Company G & 2001 & $\begin{array}{l}\text { Cardiovascular } \\
\text { Nephrology } \\
\text { Dermatology }\end{array}$ & $\begin{array}{l}\text { Head of Business Development } \\
\text { CEO }\end{array}$ \\
\hline Company $\mathrm{H}$ & 1935 & $\begin{array}{l}\text { Respiratory } \\
\text { Cardiovascular } \\
\text { Neonatology } \\
\end{array}$ & Head of Business Development \\
\hline
\end{tabular}

Table 2 provides some background information about the twelve detailed deals analyzed.

\section{Table 2. Background information about the twelve detailed deals analyzed}

\begin{tabular}{|c|c|c|c|}
\hline Deal & Licensor & Licensee & Object \\
\hline 1 & Company A & German pharma company & Nitric acid release technology \\
\hline 2 & Company B & American pharma company & $\begin{array}{c}\text { Drug in the rheumatology, diabetes, } \\
\text { respiratory and dermatology } \\
\text { therapeutic areas }\end{array}$ \\
\hline 3 & Company C & Biotech company & $\begin{array}{c}\text { Technology in preclinical phase } \\
\text { to explore the clinical potential for } \\
\text { genitourinary and gastrointestinal } \\
\text { disorders) }\end{array}$ \\
\hline 4 & Company C & Swiss pharma company & $\begin{array}{c}\text { Compound at Phase III of } \\
\text { development }\end{array}$ \\
\hline 5 & Company A & German pharma company & Not disclosed \\
\hline 6 & Company A & American pharma company & $\begin{array}{c}\text { Selection of compounds in the field } \\
\text { of ophthalmology }\end{array}$ \\
\hline 7 & Pharma company & Company D & Compound for tumors \\
\hline 8 & Company E & American biotech company & Compound for tumors \\
\hline 9 & Company F & Japanese biotech company & Gene therapy for leukemia \\
\hline 10 & Company A & Italian biotech company & Not disclosed \\
\hline
\end{tabular}




\begin{tabular}{|c|c|c|c|}
\hline 11 & Company G & $\begin{array}{c}\text { South American pharma } \\
\text { company }\end{array}$ & $\begin{array}{c}\text { Cysteine-based compound for oral } \\
\text { use in dialyzed patients for } \\
\text { commercialization in Latin America }\end{array}$ \\
\hline 12 & Company H & Not disclosed & $\begin{array}{c}\text { Compound for commercialization in } \\
\text { third world countries }\end{array}$ \\
\hline
\end{tabular}

\section{Factors influencing the Price of a Technology License}

In this section, we start with a brief description of the typical compensation structure for a technology licensing deal in the bio-pharmaceutical industry and then discuss the details of our interpretative framework by using the illustrative examples presented above.

In the context of bio-pharmaceutical technology transactions, a licensing compensation package is generally composed by:

- a certain payment (up-front payment or lump-sum) by the licensee to the licensor linked with the signing of the deal;

- fixed payments (milestones) that are tied to specific contingencies, such as filing a new drug application, beginning clinical development phases, receiving approval to market;

- variable payments (running royalties) calculated as a percentage of the net future sales of the drug incorporating the licensed technology.

The latter two are conditional payments taking place in the future only if specified events occur. As such, there is a certain amount of risk associated with these payments.

It is possible to calculate an overall value of the license with a risk-adjusted Net Present Value method. This measure named Total Deal Value is the present value for the licensor of all future cash flows adjusted for their likelihood of success rates and discounted back to the time of licensing. In the remaining of the paper, with the term "price of the license" we refer to its Total Deal Value (if not specified otherwise).

An important mechanism contemplated in our framework is that the walk-away points of the counterparts directly affect the price of the technology licenses. Several of our examples clearly illustrate this aspect.

Founded in 1996, Company A is a product-driven bio-pharmaceutical company dedicated to the development of drugs for the treatment of inflammation and cardiovascular diseases. The largest part of its revenues has been earned through out-licensing agreements with pharmaceutical companies, which have allowed Company A to focus on its lead products, 
while maximizing the value of its portfolio of non-core compounds. The Executive Vice President of Business Development at Company A recalls for instance that in 2003 Company A granted a large German pharma company an exclusive license on its patented nitric acid release technology at zero cost. Although its technology had competitive advantage over current therapies for osteoarthritis and thus had a significant value, Company A had to accept these unfavorable financial terms, because it was in deep financial distress and did not have other choices available. To put it differently, its BATNA was worth zero.

Our examples illustrate as well how target points matter in determining the price of the license - another important aspect of our framework. Company B is an Italian pharmaceutical firm founded in 1997 as a spin-off, soon after the acquisition of its Italian parent company by an American multinational pharmaceutical firm. Company B is involved in $\mathrm{R} \& \mathrm{D}$, production and marketing of innovative drugs in the rheumatology, diabetes, respiratory and other therapeutic areas. The Head of Licensing \& Business Development at Company B reports that in 2001 the firm discovered that a big American pharma company was about to launch a drug that infringed Company B's IP. As a consequence, Company B contacted the pharma company and offered it a license. Being aware of the strategic importance of that drug for the pharma company and the huge market figures at stake, it deliberately asked for an exorbitant price. According to Company B's Head of Licensing \& Business Development, this high initial price was crucial to keep the final agreed price of the license at a high level.

After this brief preliminary discussion, we now enter into more details about the factors that influence the price of technology licenses encompassed in our framework and use the examples from the bio-pharmaceutical industry with illustrative purposes. The factors included in our framework are distinguished into: (i) intrinsic characteristics of the technology; (ii) specific features of the licensor; (iii) specific features of the licensee; (iv) specific features of the dyad licensor-licensee; (v) specific features of the contract. Throughout this discussion, we also develop a set of propositions which summarize the key relationships encompassed by our framework and will hopefully inform future quantitative and confirmatory research on the subject.

\section{Intrinsic characteristics of the technology}

Technologies may differ in terms of their novelty compared to existing solutions. A pharmaceutical compound that has the potential of addressing unmet medical needs or that holds a performance advantage over existing drugs, clearly has a higher value than traditional therapies. Due to the higher value, its owner will set a more ambitious target 
point and also will be able to attract a larger number of potential licensees, each of which represents a viable alternative to the negotiated agreement. Having a larger range of suitable options, its walk-away point will be higher and so will be, according to the model in Figure 3, the price of the license. Formally stated, we argue that:

PROPOSITION 1: The more novel the technology, the higher the price of the license.

Licensed technologies may differ also in terms of their stage of development. An early stage technology, i.e. a compound that is licensed in the pre-clinical phase, bears a higher level of risk and requires larger spending in further R\&D than a late stage technology, e.g. a compound after the approval by appointed agencies (such as the US Food and Drug Administration - FDA). Higher risk and additional R\&D spending reduce the value of the technology and thus the price of the license. This is clear from the analysis of our examples when comparing two out-licensing deals signed by Company $\mathrm{C}$, a small biotech firm, born in 1999 as a spin-off of a global pharmaceutical company and headquartered in Italy, which is focused on novel therapies for diseases of the Central Nervous System and pain. As reported by the Senior Licensing Manager, the first deal with a biotech company, signed in 2004, involved a technology in preclinical phase (in order to explore the clinical potential for genitourinary and gastrointestinal disorders). Although the exact value is undisclosed, it's in the range of few million dollars. The second deal, with a large Swiss pharma company in 2006, involved a compound at Phase III for Parkinson's disease, totaled \$200 million in upfront and milestone payments. The Senior Manager of Business Development stressed that, beyond the peculiarities of the two therapeutic areas and the counterparts, the stage of development played a prominent role in the pricing definition. We summarize this component of our framework as follows:

\section{PROPOSITION 2A: The earlier the stage of development of the technology, the lower the price of the license.}

However, the earlier the stage of development of a technology, the longer the remaining duration of protection guaranteed by the patent, and thus the higher the value of the technology. Also, the earlier a technology in its development stage is, the higher is market and technical uncertainty and the more volatile are the potential future economic returns from the technology. Consistently with the Real Options theory, Leone and Oriani (2008) find that the up-front fee of a license increases with the degree of uncertainty, and so the value of the price of the license in the case of early technologies can be higher. The Executive Vice President of Business Development at Company A claims that the most valuable deals he has signed, one with a large German pharma company and one with a 
large American pharma company (the latter involving a selection of compounds in the field of ophthalmology, for a total of $\$ 30$ million in milestone payments plus royalties on any future sales) involved projects still in the research phase of development. Therefore, there is no univocal impact of the stage of development on the price of the licensed technology, and we therefore present another proposition which is antithetic to Proposition 2A:

\section{PROPOSITION 2B: The earlier the stage of development of the technology, the higher the price of the license.}

The contrasting nature of our propositions 2.a and 2.b requires careful empirical testing, to understand which one holds true and under what conditions.

As a further element, technologies offered for licensing may differ in terms of the therapeutic area that they address. Some therapeutic areas involve a higher number of patients than others, and thus the volume of drugs sold will likely be higher in such areas. For instance, orphan drugs are particular therapies that address rare medical conditions, i.e. disorders affecting fewer than 200,000 people. The larger the size of the potential market is in a certain therapeutic area, the higher the expected revenues from the sale of drugs incorporating the technology subject to licensing are, and so the price of the license. This leads us to argue that:

\section{PROPOSITION 3. The larger the prospective size of the target market of the technology, the higher the price of the license.}

A technology that is candidate for licensing may be core or non-core, depending on the relevance that it has for the owner's strategy and competitive advantage. Often non-core technologies are unintended results (i.e. by-products) of R\&D activity or become non-core as a consequence of strategic shifts by the owning firm. A non-core technology is an asset for which a firm does not want to commit additional investments, e.g., in its further development or commercialization. This means that internal exploitation is not an attractive viable alternative for the licensor since its associated benefits are lower than its costs. All other things being equal, the BATNA for the licensor of a non-core technology will be worse and lower will be its walk-away point and ultimately the price of the license. Also, being a non-core technology, the licensor psychologically does not expect a lot from its commercialization and this is reflected in a lower target point. The behavior in which a negotiator tends to settle for less is called the winner curse (Thompson, 2012). An illustrative example comes from Company D, a small biotech Italian firm, founded in 2006, whose mission is to create value by promoting and developing innovative and ethical projects that can help people with cancer. The Company D's CEO reports to have in- 
licensed at zero cost a compound from a big pharma company. Such technology was outside the core business of the big pharma, which only asked for a buy back option in the contract. This reasoning can be synthetized in the following proposition:

\section{PROPOSITION 4. The lower the relevance of the technology to the licensor's strategy} and competitive advantage, the lower the price of the license.

On the contrary, if the technology has little relevance for the prospective licensee, it means that its value creating potential for the licensee is limited. The fact that the technology has little relevance for the licensee implies that a certain number of viable alternatives are available to the licensee. In such case the licensee will be willing to pay little for its acquisition. This can be captured by the following proposition:

PROPOSITION 5. The lower the strategic relevance of the technology to the licensee, the lower the price of the license.

\section{Specific Features of the Licensor}

Prospective licensors may differ in terms of their vertical integration level. Not all firms in the bio-pharma industry cover all the steps of the value chain (from research to sales) internally. Small biotech firms usually focus on the preliminary research-oriented activities and lack the downstream complementary assets to develop and commercialize a finished drug themselves. If the licensor is not vertically integrated and thus cannot commercialize the drug itself, all other things being equal, it will have a narrower range of viable alternatives and thus a worse BATNA. This will ultimately reduce the price of the license. Company E is a medium-sized Italian biotech firm established in 2004 as a spin-off of a large US pharmaceutical company, that develops new compounds until clinical phase II. The technologies developed by Company E that have successfully reached phase II are outlicensed to capture value from them. According to the Head of Business Development, these deals play a key role for securing the long-term sustainability of its business and will constitute the main source of revenues for the firm in the future. The Head of Business Development at Company E recalls that he had to agree to unfavorable licensing terms in a deal with an American biotech company in the field of oncology in 2006, because they did not have the internal commercialization option available. On the contrary, vertically integrated firms have previously invested in downstream assets. The internal development and commercialization alternative allows to spread the fixed costs over a larger number of projects. This option has a higher value and thus may determine a higher walk-away point for the licensor. We summarize this aspect of our framework as follows: 
PROPOSITION 6. The price of the license granted by a non-fully integrated licensor is lower than the price of a license granted by an integrated licensor.

Prospective licensors may also differ in terms of their nature as private corporations or universities. Universities are not vertically integrated and thus we expect a lower price of licenses granted by universities, consistently with Proposition 6. Beside this, universities technology transfer offices do not have profit maximization as main objective, but rather the maximization of technology diffusion. Therefore, they are willing to accept lower offers and they tend to sign non-exclusive licenses, which have lower value than exclusive licenses. The business developer at a university technology transfer office interviewed, once said: "We never say no to anyone, we also sign contracts at \$5,000". Finally, they are reported to lack those negotiating and managerial skills to make the most out of their technologies (Siegel et al., 2003). The business model of Company D, a small biotech Italian firm, is to scout for promising technologies in the external environment and then inlicense them. Its CEO and co-founder says that technologies offered by universities are always the best deals on the market. The following proposition captures this line of reasoning:

\section{PROPOSITION 7. The price of a license granted by a university is lower than the price of a license granted by a private company.}

Furthermore, prospective licensors may differ in terms of their need for financial resources. Out-licensing offers an immediate way to cash out investments in $R \& D$, which is quicker than internal development and commercialization. For many firms, out-licensing is the only way to gather financial funds in the short term, to pay the salaries of the scientists and to sustain ongoing R\&D projects. This, for example, was the case of Company F, a medical biotechnology company born in 1996 as a joint venture between a renowned scientific institute and a pharma company offering service to third parties. It is now focused on discovery, $R \& D$, and clinical validation (until Phase III) of innovative therapies for the treatment of cancer. Since 2000 Company F has become a product company focusing on two investigational drugs in advanced clinical development, while in 2008 it went public on the Italian Stock Exchange. As reported by its Licensing manager, the company came to the decision to out-license one of its core technologies (related to gene therapy for leukemia for the Asian market) because raising money on the stock market was too expensive due to the recent financial crisis. When out-licensing is the only viable alternative, the BATNA of the licensor has lower value. This leads us to posit the following: 
PROPOSITION 8. The price of the license granted by a licensor with urgent need for cash is lower than the price of the license granted by a licensor without urgent need for cash.

Prospective licensors may differ in terms of their deal-making skills. Licensors that have made a large number of deals and gathered experience have developed a strong competence in preparing and negotiating out-licensing deals. Higher level of negotiating skills allows a licensor to gain better deal terms. The Head of Business Development at Company E recalls that his last licensing deals are significantly more favorable than his first deal signed with a large American pharma company, although the value of the underlying asset is comparable. He explains that experience has allowed them to refine their approach and technique. Also, licensors with higher experience may develop the reputation of being valuable technology providers. This reputation is reflected in higher target points. The Executive Vice President of Business Development at Company A reports that, after having signed more than 10 successful licensing deals, his firm is now recognized as a leading player in the inflammation and cardiovascular areas. This recognition represents an advantage when sitting at the negotiation table. This aspect is captured by the following proposition:

PROPOSITION 9: The more experienced and skilled in out-licensing the licensor, the higher the price of the license.

\section{Specific Features of the Licensee}

Prospective licensees may differ in terms of their size, being small- or medium-sized biotech firms or large multinational companies. Big pharma companies typically have high quality downstream complementary assets, i.e. market access, distribution channels, brand image, which guarantee high market penetration. The value of a technology, if transferred to these companies, is higher since the licensee's assets increase its expected profitability and lower its risk. Moreover, large pharma companies have higher availability of financial resources and thus, all other things being equal, are able to offer more for a technology. The total value of deals signed by Company A with a large American pharma company and a large German pharma company reached $\$ 800$ million, a value that no small and medium biotech firm could ever pay. The following proposition summarizes this reasoning:

PROPOSITION 10A: The price of the license transferred to a large and cash-rich licensee is higher than the price of the license transferred to a small and cash-

constrained licensee. 
However, if the prospective licensee is a leading multinational company, the licensor is willing to accept a lower price because there are other important, non-monetary returns from signing a licensing deal: returns on image, visibility, access to financing sources. The Executive VP of Business Development at Company A says that his firm was able to go public in 1999 thanks to a major licensing deal signed with an Italian biotech company. Also, he reports that after having signed a deal with a large German pharma company in 2003, Company A's stock price raised from $€ 3$ to $€ 10$. All this leads to an opposite interpretation to the one given in proposition 10A:

PROPOSITION 10B: The price of the license transferred to a large and cash-rich licensee is lower than the price of the license transferred to a small and cash-constrained licensee.

Again, we have two contrasting propositions, $10 \mathrm{~A}$ and $10 \mathrm{~B}$, which call for careful empirical testing.

Moreover, prospective licensees may differ in terms of R\&D assets and technological competencies owned. If the licensee lacks internal $R \& D$ facilities, it does not have the option of internally developing an alternative technology to the one that it is trying to license. All other things being equal, the licensee will be willing to pay more for the technology, being its BATNA more expensive. This leads us to argue that:

PROPOSITION 11: The price of the license transferred to a licensee that does not have internal $R \& D$ capabilities is higher than the price of the license transferred to a licensee with internal $R \& D$ capabilities.

\section{Specific Features of the Dyad Licensor - Licensee}

The prospective licensor and licensee may belong to different industries. In this case, large information asymmetries are likely to exist and will produce very different estimates by the counterparts about the technology value. Due to a higher volatility in the valuation of the technology, it will be more difficult to have a positive bargaining zone, i.e. an overlap between the two parties' walk-away points, as showed in Figure 2. Thus, it is less likely that a licensing deal occurs. However, if a contract is signed, a cross-sectorial technology transfer occurs. In this case, only the licensor has very detailed information on the technical potential of the technology, while only the buyer has specific knowledge of market conditions and manufacturing costs. This imperfect information will increase the perceived 
risk associated with the technology and thus will drive the technology value down. This reasoning is captured by the following proposition:

\section{PROPOSITION 12: The price of the license in a cross-sectorial technology transfer is lower than the price of a license exchanged within the same sector.}

If the prospective licensee is a competitor of the licensor, the monetary benefits accruing to the latter from licensing the technology (i.e. the "revenue effect" gained through the licensing fees), are reduced by the so-called "rent dissipation effect" deriving from increased competition in its core market (Arora et al., 2001). Therefore, if the licensor is also a manufacturer and licenses the technology to a competitor, the price of the license, which determines the revenue effect from licensing, will have to be greater than the rent dissipation effect, for licensing to occur. On the other hand, if the relationship between licensor and licensee is not competing one, e.g. between a private company and an university, then the price of the license is low, as stated by Company D's CEO and cofounder ("...technologies offered by universities are always the best deals on the market...indeed, their main goal is the maximization of technology diffusion, instead of profit maximization"). This leads us to conclude that:

PROPOSITION 13. The price of the license exchanged between two competitors is higher than the price of a license exchanged between two non-competitors.

The prospective licensor and licensee may have already had a prior business relationship. Past relations may mitigate information asymmetries and facilitate the matching between supply and demand of the technology. Since the threats from expropriation of IP are lower, a reduction in the transaction costs is reflected in a lower price of the license. In light of this, we posit the following proposition:

PROPOSITION 14. The price of the license exchanged between two parties with prior business relationship is lower than the price of the license exchanged between two parties without prior business relationship.

\section{Specific Features of the Contract}

Licensing contracts may underlie different types of technology commercialization agreements, as already noted above. Figure 4 reports a taxonomy of possible agreements in the bio-pharmaceutical industry. 


\section{Figure 4 - Different Types of Technology Commercialization Agreements Underlying Licensing}

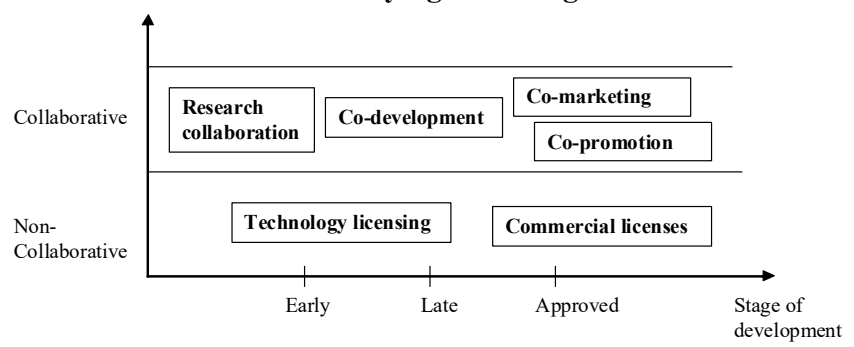

In the case of pure technology licensing, the licensor grants exploitation rights to the licensee and, in exchange of this, it receives payments but has no further involvement in the subsequent development and commercialization of the technology. Commercial licenses refer to supply and distribution agreements signed by a licensor in the attempt to access foreign markets with a licensee that operate in a separate geographic market. The technology exchanged in these transactions is at a late stage of development (preregistration obtained or even already registered compound). Transactions in the upper part of Figure 4 involve a constant and on-going partnership among the parties. In an R\&D collaboration, licensor and licensee cooperate in the subsequent R\&D effort for the specific project. In this case, both the licensor and the licensee collaborate to take the compound further along the development with their respective resources and capability. A comarketing agreement sees both the licensor and the licensee cooperate with separate distribution channels in the marketing of the same drug in a given territory. By doing so, the licensor may earn additional financial return as a manufacturer.

Holding constant the stage of development at which the technology is licensed, a noncollaborative license has a higher price than a collaborative one. This because the technology holder retains some rights over the technology for itself. The Senior Licensing Manager at Company $\mathrm{C}$ reports that in their licensing deal with a large Swiss pharma company, because Company C wanted to keep the right to co-market a Parkinson's disease treatment in Italy and Spain, they had to lower their requests for payment. This leads us to conclude:

PROPOSITION 15. The price of a collaborative license is lower than the price of a noncollaborative one.

Furthermore, licensing agreements may differ in terms of their scope. For a given IP, the licensing contract defines the precise fields of use and geographic scope within which the 
licensee has the right to exploit the technology. A broad scope license grants the licensee the use of the technology for multiple therapeutic indications and/or its commercialization in large geographical areas. Founded in 2001 in Italy, Company G is a bio-pharmaceutical company which develops new proprietary compounds up to Investigational New Drug (IND) stage with potential in cardiovascular field. Company G collaborates with biopharmaceutical companies, universities, individual scientists, to identify commercially promising innovations to be developed, patented and commercialized. Company G's activity takes the form of license agreements under which the use of its patents and preclinical packages are granted to third parties. Company G's CEO defines themselves a virtual company, which leverages knowledge and assets from third sources. The Head of Business Development of Company $\mathrm{G}$ recalls that, during the negotiation for a licensing agreement in 2006 to develop, produce and market Company G's cysteine-based product in Latin America for oral use in dialyzed patients with a South American pharma company, they calculated the value of a worldwide license and then divided by a factor larger than 1 to account that the license was valid only for the South American continent. The Head of Business Development of Company H, an Italian bio-pharmaceutical company, also mentions that when they license a drug for commercialization in a Third World country, they do not even ask for upfront payments. This leads us to posit the following proposition:

\section{PROPOSITION 16. The price of a broader scope license is higher than the price of a narrower scope license.}

\section{$\underline{\text { Other residual factors }}$}

In our analysis, we have only considered specific factors at the technology, contract and firm level that are deemed to drive the price of licenses. However, there are also contextual factors related to market conditions that affect the price of licenses.

On the supply side, an excess of compounds offered by technology owners and available for licensing drive the price of the licenses down. The Head of Business Development at Company $\mathrm{F}$ argues that in recent years there has been an oversupply of early stage technologies as many biotech firms are in strong need of funds for their R\&D projects and cannot rely on other financing sources, such as debt and equity markets.

On the demand side, the current crisis in terms of R\&D productivity of large pharma companies (Pammolli et al., 2011) has produced a high competition among these firms to find new promising compounds that can turn into blockbusters. As a result, licensors have a wide range of competing bids among which they can choose, and their BATNA will have high value. For instance, the Head of Business Development at Company H says that a key 
part of his job is to continuously in-license new drugs in order to feed Company H's sales force: "Otherwise, if they do not have anything to sell, they are just a cost". On the contrary, if only a licensee is interested to the technology, the licensor can only license the technology to this firm. The following two propositions capture this line of reasoning:

\section{PROPOSITION 17: The higher the competition among licensors in the market for technologies, the lower the price of the license. \\ PROPOSITION 18: The higher the competition among licensees in the market for technologies, the higher the prices of the license.}

Table 3 provides a list of the propositions we have introduced in this section of the paper and that represent the key components of our framework. It also identifies which of the deals included in Table 2 are useful to illustrate the different propositions. 
Table 3. Detailed view of the propositions introduced

\begin{tabular}{|c|c|c|c|c|}
\hline \multicolumn{2}{|r|}{ Proposition } & \multirow{2}{*}{$\begin{array}{c}\text { Factor included in the } \\
\text { framework }\end{array}$} & \multirow{2}{*}{$\begin{array}{c}\begin{array}{c}\text { Sub-factor included } \\
\text { in the framework }\end{array} \\
\text { Relevance }\end{array}$} & \multirow[t]{2}{*}{ Related deal } \\
\hline 1 & The more novel the technology, the higher the price of the license & & & \\
\hline $2 \mathrm{~A}$ & The earlier the stage of development of the technology, the lower the price of the license & $\begin{array}{l}\text { Intrinsic characteristics } \\
\text { of the technology }\end{array}$ & Stage of development & $3 ; 4$ \\
\hline $2 \mathrm{~B}$ & The earlier the stage of development of the technology, the higher the price of the license & $\begin{array}{l}\text { Intrinsic characteristics } \\
\text { of the technology }\end{array}$ & Stage of development & $5 ; 6$ \\
\hline 3 & The larger the prospective size of the target market of the technology, the higher the price of the license & $\begin{array}{l}\text { Intrinsic characteristics } \\
\text { of the technology }\end{array}$ & Size of target market & - \\
\hline 4 & $\begin{array}{c}\text { The lower the relevance of the technology to the licensor's strategy and competitive advantage, the } \\
\text { lower the price of the license }\end{array}$ & $\begin{array}{l}\text { Intrinsic characteristics } \\
\text { of the technology }\end{array}$ & Relevance & 7 \\
\hline 5 & The lower the strategic relevance of the technology to the licensee, the lower the price of the license & $\begin{array}{l}\text { Intrinsic characteristics } \\
\text { of the technology }\end{array}$ & Relevance & - \\
\hline 6 & $\begin{array}{c}\text { The price of the license granted by a non-fully integrated licensor is lower than the price of a license } \\
\text { granted by an integrated licensor }\end{array}$ & $\begin{array}{l}\text { Specific features of the } \\
\text { Licensor }\end{array}$ & $\begin{array}{l}\text { Level of vertical } \\
\text { integration }\end{array}$ & 8 \\
\hline 7 & $\begin{array}{c}\text { The price of a license granted by a university is lower than the price of a license granted by a private } \\
\text { company }\end{array}$ & $\begin{array}{l}\text { Specific features of the } \\
\text { Licensor }\end{array}$ & $\begin{array}{l}\text { Nature (e.g., private } \\
\text { company, university) }\end{array}$ & $\begin{array}{l}\text { Generic deals by } \\
\text { Company } \mathrm{D}\end{array}$ \\
\hline 8 & $\begin{array}{c}\text { The price of the license granted by a licensor with urgent need for cash is lower than the price of the } \\
\text { license granted by a licensor without urgent need for cash }\end{array}$ & $\begin{array}{l}\text { Specific features of the } \\
\text { Licensor }\end{array}$ & Viable alternatives & $1 ; 9$ \\
\hline 9 & The more experienced and skilled in out-licensing the licensor, the higher the price of the license & $\begin{array}{l}\text { Specific features of the } \\
\text { Licensor }\end{array}$ & Deal-making skills & $\begin{array}{l}\text { Generic deals by } \\
\text { Company A and } \mathrm{E}\end{array}$ \\
\hline $10 \mathrm{~A}$ & $\begin{array}{c}\text { The price of the license transferred to a large and cash-rich licensee is higher than the price of the } \\
\text { license transferred to a small and cash-constrained licensee }\end{array}$ & $\begin{array}{l}\text { Specific features of the } \\
\text { Licensee }\end{array}$ & $\begin{array}{l}\text { Size, availability of } \\
\text { financial resources }\end{array}$ & $\begin{array}{l}\text { Generic deals by } \\
\text { Company A }\end{array}$ \\
\hline $10 \mathrm{~B}$ & $\begin{array}{c}\text { The price of the license transferred to a large and cash-rich licensee is lower than the price of the } \\
\text { license transferred to a small and cash-constrained licensee }\end{array}$ & $\begin{array}{l}\text { Specific features of the } \\
\text { Licensee }\end{array}$ & $\begin{array}{l}\text { Size, availability of } \\
\text { financial resources }\end{array}$ & $\begin{array}{l}\text { Generic deals by } \\
\text { Company A; } 10\end{array}$ \\
\hline 11 & $\begin{array}{c}\text { The price of the license transferred to a licensee that does not have internal } R \& D \text { capabilities is higher } \\
\text { than the price of the license transferred to a licensee with internal } R \& D \text { capabilities }\end{array}$ & $\begin{array}{l}\text { Specific features of the } \\
\text { Licensee }\end{array}$ & $\begin{array}{c}\text { R\&D assets and } \\
\text { technological } \\
\text { competences owned }\end{array}$ & - \\
\hline 12 & $\begin{array}{c}\text { The price of the license in a cross-sectorial technology transfer is lower than the price of a license } \\
\text { exchanged within the same sector }\end{array}$ & $\begin{array}{l}\text { Specific features of the } \\
\text { Dyad }\end{array}$ & Reference industry & - \\
\hline
\end{tabular}




\begin{tabular}{|c|c|c|c|c|}
\hline 13 & $\begin{array}{c}\text { The price of the license exchanged between two competitors is higher than the price of a license } \\
\text { exchanged between two non-competitors }\end{array}$ & $\begin{array}{l}\text { Specific features of the } \\
\text { Dyad }\end{array}$ & Degree of competition & $\begin{array}{l}\text { Generic deals by } \\
\text { Company D }\end{array}$ \\
\hline 14 & $\begin{array}{l}\text { The price of the license exchanged between two parties with prior business relationship is lower than } \\
\text { the price of the license exchanged between two parties without prior business relationship }\end{array}$ & $\begin{array}{l}\text { Specific features of the } \\
\text { Dyad }\end{array}$ & $\begin{array}{l}\text { Presence of previous } \\
\text { business relationship }\end{array}$ & 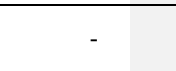 \\
\hline 15 & The price of a collaborative license is lower than the price of a non-collaborative one & $\begin{array}{l}\text { Specific features of the } \\
\text { Contract }\end{array}$ & $\begin{array}{l}\text { Degree of } \\
\text { collaboration }\end{array}$ & 4 \\
\hline 16 & The price of a broader scope license is higher than the price of a narrower scope license & $\begin{array}{l}\text { Specific features of the } \\
\text { Contract }\end{array}$ & Scope & $11 ; 12$ \\
\hline 17 & $\begin{array}{c}\text { The higher the competition among licensors in the market for technologies, the lower the price of the } \\
\text { license }\end{array}$ & Other factors & $\begin{array}{l}\text { Degree of competition } \\
\text { among licensors }\end{array}$ & - \\
\hline
\end{tabular}




\section{Conclusions}

This paper focuses on the issue of pricing in technology licensing transactions, by developing a framework grounded in negotiation research and using a number of examples drawn from the bio-pharmaceutical industry to illustrate its constitutive factors and underlying mechanisms.

\section{Implication for Research}

This study contributes to existing research by shedding light on the mechanisms underlying the formation of price in the market for technologies. First, it complements existing licensing research, which has mostly adopted a strategic- and process-oriented viewpoint so far but has neglected to investigate the factors that affect the successful completion of technology licensing deals and, in particular, the mechanisms underlying the formation of the price of the license. Second, it adds to the stream of research on the methods for the evaluation of intangible assets, and in particular patents and licenses. This research has so far attempted to develop very sophisticated monetary indicators, which aim to quantify every variable influencing the value of the license. This paper, together with very few other studies (such as Chiesa et al., 2007), calls for a deeper understanding of the qualitative factors that influence the value at which the negotiation for a technology licensing deals is likely to close. Since the final agreed price of a technology license is often very distant from the monetary value calculated through Cost, Income, or Market methods (Park and Park, 2004), it becomes of paramount importance to know the qualitative factors driving price formation. Third, this study establishes a link between negotiation and licensing research, drawing on concepts and frameworks commonly used in negotiation studies to interpret how different factors will impact the price of the technology license. This attempt to inform licensing research through a negotiation perspective is an important contribution of this paper which will hopefully inform future studies in the field.

\section{Implication for Practice}

Of course, given our methodological approach and the focus on the bio-pharmaceutical industry, the results of this paper cannot be generalized to any population of firms or markets. The relationships between different categories of factors and the price of the technology license which underlie the propositions discussed in Section 5 will have to be tested through confirmatory and quantitative research, hopefully also outside the biopharmaceutical industry, before prescriptive and normative behaviors could be suggested. That said, we believe this paper holds important implications for Licensing Managers, 
Business Development Managers, R\&D Managers, and all those employees involved in the commercialization and licensing of technologies. First, it encourages them to use the frameworks and concepts established in negotiation research to develop a more finegrained understanding of the mechanisms through which price is formed in technology licensing deals. Linked to this, the paper sheds light on the importance to carefully prepare the negotiation for a technology licensing deal, by adopting the perspective of the counterpart and anticipating the decisions it can make during negotiation. Second, this study highlights the importance of taking into careful account a set of qualitative, nonmonetary factors, in the estimation of the value of a technology license. Licensing Managers and Business Development Managers are often too much interested in identifying a single, precise monetary estimation of the value of a technology and they forget the importance of developing a complete understanding of the entire context surrounding the deal and influencing the expected value of the transaction. This paper provides some preliminary insights and illustrative examples that will hopefully help practitioners overcome this limitation.

\section{Limitations and Avenues for Future Research}

Of course, the paper suffers of a number of limitations, which however will hopefully open up avenues for future research. First, as already mentioned, this study has an exploratory nature and its results cannot be generalized to any populations of firms or markets. Our aim was to produce new knowledge, by integrating negotiation research and illustrative insights from the bio-pharmaceutical industry, and to crystallize it in a set of research propositions that should be tested in the future, to understand whether our hypothesized relationships hold true, in the bio-pharmaceutical industry and also outside it. To do so, it would be possible to select a sample of technology licensing deals by using professional databases such as the Financial Valuation Group Intellectual Property (FVGIP) database (Leone and Reichstein, 2012) or data made available by intermediaries such as yet2.com. By developing proper scales to measure the independent variables included in our propositions (e.g., for Proposition 1, the level of novelty of the technology) and asking a panel of experts to independently assign values to these variables for each transaction in the sample, it would be possible to test for correlations with the price of the licensing deal made available by the above-mentioned data sources. Second, the study focuses on a set of important factors affecting the price of technology licenses, but it is likely that other variables exist that substantially affect the price at which the deal is close. Therefore, future exploratory research is needed to unearth these factors, which could be especially important in industries different from the bio-pharmaceutical one. Finally, we focus in this paper on licensing as the main contractual form in the market for technologies. It would be 
interesting to study the factors affecting the price at which technologies are traded in the case of other contractual forms through which technology can be traded.

\section{References}

Aggarwal, V.A. and Hsu, D.H. (2009). Modes of cooperative R\&D commercialization by start-ups, Strategic Management Journal, Vol. 30, pp. 835-864.

Allarakhia, M. and Walsh, S. (2011). Managing knowledge assets under conditions of radical change: the case of the pharmaceutical industry, Technovation, Vol. 31, pp. 105117.

Anand, B. N. and Khanna, T. (2000). The structure of licensing contracts, Journal of Industrial Economics, Vol. 48, n. 1, pp. 103-135.

Arora, A. and Ceccagnoli, M. (2006). Patent Protection, Complementary Assets, and Firms' Incentives for Technology Licensing, Management Science, Vol. 52, n. 2, pp. 293-308.

Arora, A. and Gambardella, A. (2008). Ideas for rent: an overview of markets for Technology, DIME Working Paper on Intellectual Property Rights, n. 83.

Arora, A., Fosfuri, A. and Gambardella, A. (2001). Markets for technology: the economics of innovation and corporate strategy, Cambridge MA: The MIT Press.

Arora, A., Fosfuri, A. and Rønde, T. (2013). Managing Licensing in a Market for Technology, Management Science, Vol. 59, n. 5, pp. 1092 - 1106.

Arrow, K. J. (1996). The Economics of Information: An Exposition, Empirica, Vol. 23, n. 2, pp. 119-128.

Baldi, F. and Trigeorgis, L. (2015). R\&D Licensing in Biopharmaceuticals: How to Structure a Good Deal, Proceedings of the $19^{\text {th }}$ Annual International Conference on Real Options, Athens. 
Beggs, A. W. (1992). The licensing of patents under asymmetric information, International Journal of industrial Organization, Vol. 10, n. 2, pp. 171-191.

Bianchi, M., Chiesa, V. and Frattini. F. (2011a). Selling technological knowledge: how firms can win the complexities of technology transactions, Research-Technology Management, Vol. 54, n. 2, pp. 18-26.

Bianchi, M., Chiaroni, D., Chiesa, V. and Frattini, F. (2011b). Organizing for external technology commercialization: evidence from a multiple case study in the pharmaceutical industry, R\&D Management, Vol. 41, n. 2, pp. 120-137.

Bianchi, M., Cavaliere, A., Chiaroni, D., Frattini. F. and Chiesa, V (2011c). Organisational modes for Open Innovation in the bio-pharmaceutical industry: An exploratory analysis, Technovation, Vol. 31, n. 1, pp. 22-33.

Bianchi, M., Frattini, F., Lejarraga, J. and Di Minin, A. (2014). Technology exploitation paths: combining technological and complementary resources in new product development and licensing, Journal of Product Innovation Management, Vol. 31, n. S1, pp. 146-169.

Borshell N. and Ahmed T. (2012). Approaches to Valuation of Pharmaceutical Licensing Deals. Oxford Science Park, Oxford, UK: PharmaVentures Ltd Florey House.

CAP GEMINI ERNST \& YOUNG. (2001), Perspective on Life Science, 3(Fall).

Chatterji, D. (1996). Accessing external sources of technology, Research-Technology Management, Vol. 39, n. 2, pp. 49-56.

Chiesa, V., Gilardoni, E. and Manzini, R. (2003). The valuation of technology in buycooperate-sell decisions, Proceedings of the $R \& D$ Management Conference, Manchester, pp. 1-11.

Chiesa, V. and Frattini, F. (2009). Evaluation and Performance Measurement of Research and Development: Techniques and Perspectives for Multi-Level Analysis, Cheltenham, UK: Edward Elgar.

Chiesa, V., Frattini, F., Gilardoni, E., Manzini, R. and Pizzurno, E. (2007). Searching for factors influencing technological asset value, European Journal of Innovation Management, Vol. 10, n. 4, pp. 467-488. 
Danneels, E. and Frattini, F. (2018). Finding Applications for Technologies Beyond the Core Business, MIT Sloan Management Review, Spring 2018 Issue

De Massis, A., Frattini, F., Kotlar, J., Messeni Petruzzelli, A. and Wright, M. (2016). Innovation through Tradition: Lessons from Innovative Family Businesses and Directions for Future Research. Academy of Management Perspectives, Vol. 30, n. 1, pp. 93-116.

Dimasi J.A. (2001). New drug development in U.S. 1963-1999. Clinical Pharmacology Therapeutics, Vol. 69, pp. 286-296.

Escher, J-P. (2005). Technology marketing in technology-based enterprises - the process and organization structure of external technology deployment, PhD Dissertation No. 15886, ETH Zurich.

Etikan, I., Musa, S. A. and Alkassim, R. S. (2016). Comparison of Convenience Sampling and Purposive Sampling, American Journal of Theoretical and Applied Statistics, Vol. 5, n. 1, pp. 1-4.

Finnegan M.B. and Mintz, H.H. (1978). Determination of a Reasonable Royalty in Negotiating a License Agreement: Practical Pricing for Successful Technology Transfer, Licensing Law and Business Report 1, Vol. 1, n. 2, pp. 13-24.

Fosfuri, A. (2006). The Licensing Dilemma: Understanding the Determinants of the Rate of Technology Licensing, Strategic Management Journal, Vol. 27, n. 12, pp. 1141-58.

Gambardella, A. and Giarratana, M.S. (2007). General Technologies, Product-Market Fragmentation and the Market for Technology: Evidence from the Software Security Industry, Working paper.

Gambardella, A. and Giarratana, M.S. (2013). General Technological Capabilities, Product Market Fragmentation, and Markets for Technology, Research Policy, Vol. 42, n. 2, pp. 315-325.

Gambardella, A., Giuri, P. and Luzzi, A. (2007). The Market for Patents in Europe, Research Policy, Vol. 36, n. 8, pp. 1163-1183.

Gans, J.S. and Stern, S. (2003). The product market and the market for "ideas": commercialization strategies for technology entrepreneurs, Research Policy, Vol. 32, n. 2 , pp. 333-350. 
Hagedoorn, J. (1993). Understanding the rationale of strategic technology partnering: interorganizational modes of cooperation and sectoral differences, Strategic Management Journal, Vol. 14, n. 5, pp. 371-385.

Hall, B.H. and Ziedonis, R.H. (2001). The Patent Paradox Revisited: An Empirical Study of Patenting in the US Semiconductor Industry, 1979-95, Rand Journal of Economics, Vol. 32, n. 1, pp. 101-128.

Hu, Y., McNamara, P. and McLoughlin, D. (2015). Outbound open innovation in biopharmaceutical out-licensing, Technovation, Vol. 35, n. 1, pp. 46-58.

Jensen, P.H., Palangkaraya, A. and Webster, E. (2015). Trust and the market for technology, Research Policy, Vol. 44, n. 2, pp. 340-356.

Kani, M. and Motohashi, K. (2012). Understanding the technology market for patents: New insights from a licensing survey of Japanese firms, Research Policy, Vol. 41, n. 1, pp. $226-$ 235.

Kemmerer, J.E. and Lu, J. (2008). Profitability and Royalty Rates Across Industries: Some Preliminary Evidence. KPMG Global Valuation Institute, November 2012. Available at SSRN: http://ssrn.com/abstract=1141865,

King, K. (2002). The Value of Intellectual Property, Intangible Assets and Goodwill, Journal of Intellectual Property Rights, Vol. 7, pp. 245-248.

Lane C. and Probert, J. (2007). The External Sourcing of Technological Knowledge by US Pharmaceutical Companies: Strategic Goals and Inter-organizational Relationships, Industry and Innovation, Vol. 14, n. 1, pp. 5-25.

Lax, D.A. and Sebenius J.K. (1986). The Manager as Negotiator: Bargaining for Cooperation and Competitive Gain, NY: Free Press.

Leone M.I. and Oriani R. (2008). Explaining the Remuneration Structure of Patent Licenses, Proceeding of the 2008 Annual Meeting of the Academy of Management, Anaheim, California, August.

Leone, M. I. and Reichstein, T. (2012). Licensing - in fosters rapid invention! the effect of the grant - back clause and technological unfamiliarity, Strategic Management Journal, Vol. 33, n. 8, pp. 965-985. 
Lichtenthaler, E. (2004). Organising the external technology exploitation process: current practices and future challenges, International Journal of Technology Management, Vol. 27 , n. $2 / 3$, pp. 254-271.

Lichtenthaler, U. and Ernst, H. (2007). Developing reputation to overcome the imperfections in the markets for knowledge, Research Policy, Vol. 36, n. 1, pp. 37-55.

Muir, A. (1986). Rationalizing Royalties, Les Nouvelles, Journal of the Licensing Executives Society, Vol. 21, n. 2, pp. 98-103.

Pammolli, F., Magazzini, L. and Riccaboni, M. (2011). The productivity crisis in pharmaceutical R\&D, Nature Reviews Drug Discovery, Vol. 10, pp. 428-438

Park, Y. and Park, G. (2004). A new method for technology valuation in monetary value: procedure and application, Technovation, Vol. 24, n. 5, pp. 387-394.

Raiffa H. (1982). The Art and Science of Negotiation, Cambridge, Massachusetts: Harvard University Press.

Razgaitis, R. (2003). Valuation and Pricing of Technology-Based Intellectual Property, New Jersey: John Wiley \& Sons.

Razgaitis, R. (2004). US/Canadian Licensing in 2003: Survey Results, Journal of the Licensing Executive Society, Vol. 34, n. 4, pp. 139-151.

Razgaitis, R. (2006). US/Canadian Licensing in 2005: Survey Results, Les Nouvelles, Vol. 41, pp. 641-651.

Roberts, E.B. (2001). Benchmarking global strategic management of technology, Research-Technology Management, Vol. 44, n. 2, pp. 25-36.

Rogers, M.J., Maranas, C.D. and Ding, M. (2004). Valuation and design of pharmaceutical R\&D licensing deals, American Institute of Chemical Engineers, Vol. 51, n. 1, pp. 198209.

Sakakibara, M. (2010) An empirical analysis of pricing in patent licensing contracts, Industrial and Corporate Change, Vol. 19, n. 3, pp. 927-945. 
Siegel, D. S., Waldman, D. A., Atwater, L. E. and Link, A. N. (2003). Commercial knowledge transfers from universities to firms: improving the effectiveness of universityindustry collaboration, Journal of High Technology Management Research, Vol. 14, n.1, pp. 111-133.

Smith, G.V. and Parr, R.L. (2000). Valuation of Intellectual Property and Intangible Assets (Third Edition), New York: John Wiley \& Sons.

Teece, D.J. (1986). Profiting from technological innovation: implications for integration, collaboration, licensing and public policy, Research Policy, Vol. 15, n.6, pp. 285-305.

Thompson, L.L. (2012). The Mind and Heart of the Negotiator (Second Edition), Upper Saddle River: Prentice Hall.

Wang, L., Plump, A. and Ringel, M. (2015). Racing to define pharmaceutical R\&D external innovation models, Drug Discovery Today, Vol. 20, n.3, pp. 361-370.

West, J. and Bogers, M. (2014). Leveraging External Sources of Innovation: A Review of Research on Open Innovation. Journal of Product Innovation Management, Vol. 31, n.4, pp. 814-831.

Wu A. YH., Little, V.J. and Low, B. (2016). Inbound open innovation for pharmaceutical markets: a case study of an anti-diabetic drug in-licensing decision, Journal of Business \& Industrial Marketing, Vol. 31, n. 2, pp. 205-218.

Zuniga, P. and Guellec, D. (2009). Who Licenses Out Patents and Why? Lessons from a Business Survey, STI Working Paper n. 2009/5. 